\title{
WHAT TOURISM PRODUCT ATTRIBUTES ARE DOMINANT INFLUENCING REVISIT INTENSION TO CULINARY TOURISM DESTINATION?
}

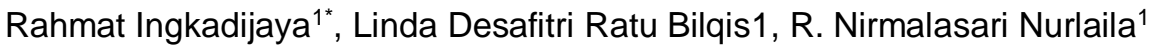 \\ ${ }^{1}$ Sekolah Tinggi Pariwisata Trisakti, Indonesia \\ *e-mail: rachmatingkadijaya@stptrisakti.ac.id
}

\begin{abstract}
Abstrak
Wisata kuliner merupakan salah satu bentuk pariwisata yang sedang berkembang saat ini. Kajian mengenai preferensi wisatawan kuliner akan sangat membantu bagi pengembangan bentuk pariwisata ini di masa depan. Penelitian ini bertujuan untuk menganalisis pengaruh atribut produk wisata yang terdiri atas daya tarik wisata, aksesibilitas, dan amenitas terhadap minat berkunjung kembali ke sebuah kawasan wisata kuliner. Penelitian ini menggunakan metode survey. Kuesioner disebarkan kepada 100 orang wisatawan domestik yang berkunjung ke kawasan wisata kuliner di Kota Bogor. Metode analisis data menggunakan analisis deskriptif, regresi berganda, uji- $F$ dan uji-T. Hasil penelitian ini menunjukkan bahwa daya tarik wisata berpengaruh positif dan signifikan terhadap minat berkunjung kembali, sedangkan aksesibilitas dan amenitas tidak berpengaruh terhadap minat berkunjung kembali. Namun, daya tarik wisata, aksesibilitas, dan amenitas secara simultan berpengaruh positif dan signifikan terhadap minat berkunjung kembali. Penelitian ini menyimpulkan bahwa atribut produk wisata kuliner yang dominan adalah daya tarik wisata yang meliputi ragam makanan dan kekhasan makanan.
\end{abstract}

Kata Kunci: Atribut Produk Wisata; Minat Berkunjung Kembali; Wisata Kuliner; Wisatawan Domestik

\begin{abstract}
Culinary tourism is a form of tourism that is currently developing. Studies on the preferences of culinary tourists will be beneficial for the development of this form of tourism in the future. This study analyzes the influence of tourism product attributes: tourist attraction, accessibility, and amenities on revisit intention to a culinary tourism area. This study used a survey method. The questionnaire was distributed to 100 domestic tourists who visited the culinary tourism area in Bogor City, Indonesia. Methods of data analysis using descriptive analysis, multiple regression, F-test, and T-test. This study indicated that tourist attraction has a positive and significant effect on revisit intention, while accessibility and amenities do not affect revisit intention. However, tourist attraction, accessibility, and amenities simultaneously have a positive and significant effect on revisit intention. This study concluded that the dominant attribute of culinary tourism products is a tourist attraction that includes a variety of food and distinctiveness.
\end{abstract}

Keywords: Tourism Product Attributes; Revisit Intention; Culinary Tourism; Domestic Tourist

This is an open access article under the CC BY-SA license. Copyright (C) 2021 by Author. Published by Universitas Pendidikan Ganesha.

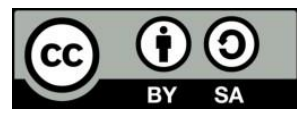




\section{INTRODUCTION}

One form of tourism that is growing rapidly is culinary tourism. Therefore, tourism industry players in each country should understand the importance of developing culinary tourism both on a local, regional or national scale (UNWTO, 2013). Culinary delights play an important role in increasing tourist attractiveness, increasing the number of tourists, enhancing the tourist experience, strengthening regional identity, and stimulating growth in other sectors. It is very clear that culinary delights contribute to a sustainable influence on tourist destinations (Steinmetz, 2010).

The term culinary tourism is broadly speaking not just food or cuisine but a unique and memorable experience (Scarpato, 2002). Several countries have started to incorporate local cuisine into the marketing of their tourist destinations. For example, in Singapore the government has developed a marketing effort for Singapore's New Asian Cuisine to attract visitors to enjoy its cuisine that combines Eastern and Western flavors (Scarpato, 2002). The country started its first Singapore Food Festival and World Gourmet Summit in 1997, which is held twice a year. Singapore has been working hard to develop its food image on a regular basis to become a top food destination in Asia.

Kivela \& Chu (2001) point out that Hong Kong cuisine is an important factor that positively contributes to high-quality travel experiences and tourists' desire to return to Hong Kong. Okumus, et al. (2007) show that Hong Kong is developing in producing a gastronomic market due to its strategic position by marketing local and international cuisine to tourists.

Long (2004) defines culinary tourism as a way to experience other cultures through food. Local food from a country is associated with the country's culture and image, also represents a core expression of a destination's intangible heritage, and through its dining experience, tourists can get a truly authentic culture (Okumus et al., 2007). Ryan (2002) considers food to be the most enjoyable activity tourists engage in during their vacation. Frochot (2013) explains that tourism-related food can enable tourists to achieve the desired relaxation goals. In addition, research conducted by Sparks, et al. (Sparks, Bowen, \& Klag, 2003)show that eating out provides experiences that contribute to tourists' enjoyment or satisfaction with tourist destinations and the intention to return.

Quan \& Wang (2004) developed a conceptual model describing the role of food consumption in tourism. They concluded that food is an important means of selling the distinctiveness and culture of a tourist destination. Furthermore, food no longer only occupies a supporting role but often becomes a driving force for people to visit a tourist destination (Gatley, 2006).

Culinary tourism has the potential to be developed, now exploring the culinary delights of a destination has become an important part of the itineraries or travel plans that tourists will undertake, compared to visiting landmarks that are already too exposed or going for a walk to shop. Culinary exploration has become the main goal of travel, which means tourists deliberately choose a destination because of its culinary appeal (Kautsar, 2018). Tourists who come to culinary tourism destinations are usually interested in the culinary specialties of the target area, they are looking for these culinary delights to try and enjoy. They feel that their tourism experience is incomplete if they don't try the culinary specialties of the region they are visiting.

One of the culinary tourism destination in West Java Province is Bogor City. The citizens of Bogor City have high creativity in the culinary field so that the City of Bogor is until now known as the city of culinary tourism. Bogor City is one of the

Jurnal IImu Sosial dan Humaniora| 260 
tourist destinations that is rich in offering various types of culinary. Bogor's special food menu is one of the culinary tourism products with unique characteristics, has a cultural identity, and is a symbol of the region.

This is reflected in the establishment of a place that sells typical dishes of Bogor City, starting from a simple concept to a classy type of restaurant that has been around for a long time, even from generation to generation so that tourists who visit are very familiar with this place because it has been established for a long time. The place that sells typical Bogor food is known as Jalan Suryakencana Culinary. The interest of tourists in visiting Suryakencana Street Culinary can be observed during the holiday period, almost every food and beverage sales place on Jalan Suryakencana is crowded with tourists.

Table 1. Tourist Arrivals in Bogor City

\begin{tabular}{lrr}
\hline \multirow{2}{*}{ Type of Tourist } & \multicolumn{2}{c}{ Year } \\
\cline { 2 - 3 } & 2018 & 2019 \\
\hline Domestic & 7.573 .402 & 8.709 .412 \\
Foreign & 392.585 & 451.473 \\
\hline Total & 7.965 .987 & 9.160 .885 \\
\hline
\end{tabular}

Source: Dinas Pariwisata dan Kebudayaan Kota Bogor, 2020

This data shows that the development of tourist visits to the city of Bogor has increased. This shows that Bogor City is a tourist destination that continues to be of interest to tourists and its main attraction is culinary delights, both traditional and contemporary as a result of the creativity and innovation of the community and culinary entrepreneurs.

However, with the increasing density of Bogor City, both by the number of its population and the number of vehicles and buildings, it can affect the comfort and convenience of tourists. Tourists are less comfortable and it is rather difficult to reach the culinary area due to traffic jams. Access to tourist destinations is one of the main attributes that attract tourists, in addition to tourist attraction and amenities. All tourist destinations require adequate accessibility, tourist attraction, and amenities if they want to attract a large number of tourists (Holloway et al., 2009).

The attribute of the tourism product itself is the overall service that tourists get and feel or enjoy since they leave their place of residence, arrive at the tourist destination that they have chosen and return to the home where they originally left (Suwantoro, 2004). There are three main tourism product attributes, namely accessibility, tourist attraction, and amenities.

Accessibility can be interpreted as a variety of things related to tourist access when they want to visit a tourist destination. This access includes access to information and access to transportation. Tourist attraction includes everything that can be enjoyed by tourists, such as can be seen, heard, felt or done, whether in the form of natural, cultural or creative results of the people. Amenities are supporting facilities of a tourist destination that are provided to meet the needs of tourists while in a tourist location. Starting from basic facilities such as the existence of toilets, places of worship, parking lots, rest areas and places to eat. In addition, the existence of hotels or inns, restaurants or culinary places, places to buy souvenirs and all the supporting capacities that can complement tourism activities. The completeness and comfort of the amenities that a tourist destination has, will influence tourists' considerations and decisions when they want to visit. The existence of these amenities will also affect the length of stay of tourists at tourist sites.

In addition, tourists will return to a tourist destination if the destination's offer is attractive. The tourism product attribute is one of the many factors that cause tourists to visit a tourist spot. If tourists feel a satisfaction with a tourist destination, they

Jurnal IImu Sosial dan Humaniora| 261 
will repeat their visit to that destination again and then recommend it to others (Rageh, Melewar, \& Woodside, 2013).

Many researchers agree that repeat visitors tend to stay longer at a destination, participate more intensively in consumptive activities, are more satisfied, and share positive word of mouth (Lehto et al., 2004; Zhang et al., 2018). The intention to revisit a tourist destination can be seen as a type of post-consumption behavior (Cole \& Scott, 2004) and has been defined as a visitor who repeats an activity or revisits a destination (Baker \& Crompton, 2000). This also relates to visitors' assessments of preferences or plans to revisit the same destination (Khasawneh \& Alfandi, 2019) or willingness to recommend these destinations to others (Chen \& Tsai, 2007).

Revisit intension is a behavior that appears in response to an object that indicates a desire to make a repurchase (Umar, 2003). (Lin, 2014) explains that interest in visiting again is to repeat activities to revisit a destination and there are two dimensions of interest in returning to visit, namely (1) a desire to provide recommendations to other parties, and (2) the desire to come to visit again.

It is considered very important to conduct research on the influence of the attributes of tourism products on the interest in returning to the culinary tourism area of Jalan Suryakencana, Bogor, so this study aims to analyze (1) the effect of tourist attraction on revisit intension, (2) the effect of accessibility on revisit intension, (3) the effect of amenities on revisit intension, and (4) the simultaneous effect of tourist attractions, accessibility, and amenities on revisit intension.

In addition, this study also proposes several hypotheses as follows.

$\mathrm{H} 1$ : There is an effect of tourist attraction on revisit intension.

$\mathrm{H} 2$ : There is an effect of accessibility on revisit intension.
H3 : There is an effect of amenities on revisit intension.

H4 : There is a simultaneous effect of tourist attraction, accessibility and amenities on revisit intension.

\section{METHODS}

This study used a survey method with a questionnaire as the main instrument to collect data. The place chosen for this research is the Culinary Tourism Area of Jalan Suryakencana, Bogor City. This area was chosen because this place sells traditional foods which are legendary and have been passed down from generation to generation. This area is a historic Chinatown area, both in terms of Chinese culture and culinary delights.

The population in this study were domestic tourists visiting the city of Bogor. According to data from the Bogor City Tourism and Culture Office in 2019 the total was $3,749,069$. To determine the number of samples, Slovin's formula is used with a margin of error of $0.1(10 \%)$ so that the number of samples is 100 respondents. The sampling technique used was convenience sampling. The questionnaire was distributed to tourists who were at the location and were willing to fill it out.

Measurement of data in this study using a Likert scale. This scale is used to measure individual attitudes about an object of attitude. Each statement or question that is asked will be given a choice of answers in the form of support expressed in words and each of them will be given a score of 1 (strongly disagree), 2 (disagree), 3 (neutral), 4 (agree), and 5 (strongly agree)

The collected data were analyzed using descriptive analysis and multiple regression analysis using SPSS software.

Jurnal IImu Sosial dan Humaniora| 262 


\section{RESULTS AND DISCUSSION Respondent Profile}

Based on gender, the most respondents were female, namely $61 \%$ and the rest were male at $39 \%$. Thus the majority of respondents in this study were women.

In terms of age, the most respondents aged between 29-39 years were $46 \%$, and the second order was respondents aged $40-50$ years at $26 \%$. This shows that the majority of respondents are young and productive tourists.

When viewed from employment, the largest proportion of respondents with status as private employees is $34 \%$, while $28 \%$ are civil servants. This shows that the culinary area of Jalan Suryakencana is more visited by tourists with the status of employees, namely private employees and civil servants.

Based on the origin of the respondents, the majority of respondents came from Jakarta at $33 \%$, then from Depok at $32 \%$. This shows that the culinary area of Jalan Suryakencana is a favorite of tourists who come from cities around the city of Bogor, namely Jakarta and Depok.

The majority of respondents got information about this culinary tourism place from friends / relatives, namely $64 \%$ and the rest got information on this culinary tourism place from social media by $36 \%$. This shows that word of mouth is the main means for tourists to get culinary tourism information in the city of Bogor.

Respondents who visit the culinary area of Jalan Suryakencana are loyal respondents. It is proven that $51 \%$ have visited this area more than 5 times. Others have visited the area $2-3$ times $(31 \%)$ and 4-5 times (11\%).
Table 2. Respondent Profile

\begin{tabular}{|c|c|}
\hline Characteristics & Percentage \\
\hline \multicolumn{2}{|l|}{ Gender } \\
\hline - Men & 31.0 \\
\hline - Women & 69.0 \\
\hline \multicolumn{2}{|l|}{ Age } \\
\hline - 18 - 28 years & 23.0 \\
\hline - 29 - 39 years & 46.0 \\
\hline - $40-50$ years & 26.0 \\
\hline - $>50$ years & 5.0 \\
\hline \multicolumn{2}{|l|}{ Profession } \\
\hline - Housewifes & 18.0 \\
\hline - Students & 7.0 \\
\hline - Government employees & 28.0 \\
\hline - General employees & 34.0 \\
\hline - Entrepreneur & 13.0 \\
\hline \multicolumn{2}{|l|}{ Respondent origin } \\
\hline - Jakarta & 33.0 \\
\hline - Depok & 32.0 \\
\hline - Tangerang and Bekasi & 13.0 \\
\hline - Bandung & 9.0 \\
\hline \multicolumn{2}{|l|}{ Information } \\
\hline - Friends / relatives & 64.0 \\
\hline - Social media & 34.0 \\
\hline \multicolumn{2}{|l|}{ Frequency of visits } \\
\hline - First time & 7.0 \\
\hline - 2 - 3 times & 31.0 \\
\hline - 4 - 5 times & 11.0 \\
\hline - $\quad>5$ times & 51.0 \\
\hline
\end{tabular}

\section{Tourism Product Attributes}

The attributes of tourism products in this study consist of three attributes, namely tourist attraction, accessibility, and amenities. Of the three attributes, tourist attraction is the attribute that has the highest mean score, namely 3.91. This shows that what is the advantage of culinary tourism on Jalan Suryakencana is the tourist attraction. The most prominent components of tourist attraction, according to respondents, are food variation (mean score: 4.17) and food peculiarities (mean score: 4.07). This culinary tourism area does provide a variety of typical foods from the city of Bogor. Some of the specialties that are already difficult to find elsewhere, in this area are available.

Jurnal IImu Sosial dan Humaniora | 263 
From the accessibility component, respondents consider the "mileage" component to be the most prominent. This is in accordance with the profile data of respondents who mostly come from Jakarta and Depok, which are close to the city of Bogor. The short distance is a consideration for them to choose this culinary tourism area.

Amenities are the attributes of tourism products with the smallest mean score when compared to the attributes of other tourism products. Respondents do not really think that amenities are important. However, there is one amenity component to consider, namely lodging. In the city of Bogor, there are indeed many hotels so that tourists have no trouble finding lodging.

Table 3. Mean Score of Tourism Product Attributes

\begin{tabular}{|c|c|}
\hline & $\begin{array}{l}\text { Mean } \\
\text { Score }\end{array}$ \\
\hline Tourism Product Attributes & 3.49 \\
\hline Attraction & 3.91 \\
\hline - Distinctiveness of food & 4.07 \\
\hline - The taste of food & 3.73 \\
\hline - Food appearance & 3.95 \\
\hline - Food quality & 3.74 \\
\hline - Food prices & 3.81 \\
\hline - Food portions & 3.92 \\
\hline - Variety of food & 4.17 \\
\hline Accessibility & 3.66 \\
\hline - Strategic location & 3.82 \\
\hline - Ease of access & 3.87 \\
\hline - Mileage & 4.16 \\
\hline - Road conditions & 2.77 \\
\hline Amenities & 2.89 \\
\hline - Eating place capacity & 2.96 \\
\hline - Parking & 2.43 \\
\hline - Worship place & 2.85 \\
\hline - Toilet & 2.63 \\
\hline - Lodging & 3.59 \\
\hline
\end{tabular}

\section{Revisit Intention}

In revisit intension variable, it can be seen that the mean score is 3.65. Respondents are interested in returning to the culinary area of Jalan Suryakencana and are willing to recommend this place to their families and others

Table 4. Mean Score of Revisit Intension

\begin{tabular}{cr}
\hline & $\begin{array}{r}\text { Mean } \\
\text { Score }\end{array}$ \\
\hline Revisit Intension & 3.65 \\
\hline$-\quad$ Recommend to families & 3.64 \\
- Recommend to friends & 3.66 \\
$\quad \begin{array}{l}\text { Recommend to people } \\
\text { other than family and } \\
\text { friends }\end{array}$ & 3.60 \\
- Want to come back to \\
$\quad \begin{array}{l}\text { this culinary place } \\
\text { Inviting other people to } \\
\text { visit this culinary place }\end{array}$ \\
\hline
\end{tabular}

\section{The Effect of Tourist Attraction on Revisit Intension}

The results of hypothesis testing indicate that tourist attraction has a significant effect on revisit intension. In other words, the components of a tourist attraction such as variety, uniqueness, appearance, portion, price, quality, and taste of food have succeeded in attracting tourists to return to the culinary tourism area of Jalan Suryakencana, Bogor City.

In the culinary tourism area of Jalan Suryakencana, tourists can easily find various kinds of food or snacks typical of Bogor City. These foods are known for their delicious taste and low prices. This fact has encouraged tourists to return to this area at a later date.

The results of this study are in line with research conducted by Muflikhah, et al. (2018) which shows that tourist attraction has a significant effect on the decision to visit the Floating Market Lembang, Bandung. So, the results of this study reinforce the statement that tourist 
attractiveness in culinary tourism is the main thing.

\section{The Effect of Accessibility on Revisit Intension}

The hypothesis which states that accessibility affects revisit intension is rejected. This indicates that accessibility is not an attribute of tourism products that prevents tourists from returning to culinary tourism areas.

Access to the culinary tourism area of Jalan Suryakencana is very easy because it is not far from the Jagorawi toll exit. This area is also strategically located, in the city center and close to the Bogor Botanical Gardens.

Accessibility components, such as strategic location, easy access, short mileage, and good road conditions, are not factors that cause tourists to take culinary tours again in this culinary tourism area.

The results of this study are also in line with the results of research by Muflikhah, et al. (2018) which shows that accessibility in tourism product attributes does not have a significant effect on the decision to visit the Floating Market Lembang, Bandung. Thus, this study confirms that in culinary tourism activities, accessibility is not an important attribute that determines the decision of tourists to visit again.

\section{The Effect of Amenities on Revisit Intension}

The hypothesis which states that amenities affect revisit intension to culinary tourism areas is also rejected. This indicates that amenities such as accessibility are not the main consideration for tourists to return to culinary tourism areas. Tourists are more concerned with the attractiveness of their tour, namely things related to food. They come to enjoy the typical food of the city of Bogor. Even though the available supporting facilities are still lacking, such as in terms of the capacity of the place to eat, which is still inadequate, so many tourists are willing to queue to be able to enjoy the food they want. Narrow parking space because it uses the road to park vehicles. Facilities for places of worship and toilets that are not yet centralized. However, these things do not dampen the intention of returning tourists.

The results of this study are also in line with research conducted by Muflikhah, et al. (2018) which shows that the amenities in the attributes of tourism products do not have a significant effect on the decision to visit the Floating Market Lembang, Bandung. Once again, this study emphasizes that amenities are not the main attribute that causes tourists to want to return to culinary tourism areas.

\section{The Simultaneous Effect of Tourist Attraction, Accessibility and Amenities on Revisit Intension}

Hypothesis test results show that simultaneously tourist attraction, accessibility, and amenities have a significant effect on revisit intension. So, although partially the accessibility and amenities have no effect, simultaneously with the tourist attraction it affects revisit intension. The results of this study are in line with research conducted by Mayasari \& Budiatmo (2017) which shows that the attributes of tourism products simultaneously have a positive and significant effect on the decision to visit Wildlife Park, Semarang.

The results of this study indicate that the tourist attraction, accessibility, and amenities, if developed and addressed simultaneously, will increase the interest of tourists to return to the culinary tourism area. Food of high quality and taste supported by easy access and adequate facilities will increase the comfort and satisfaction of tourists, which in turn will generate interest in returning to visit. Interest in visiting again arises because of a pleasant and satisfying previous experience 
(Baker \& Crompton, 2000; Chen \& Tsai, 2007; Cole \& Scott, 2004; Khasawneh \& Alfandi, 2019; Rageh et al., 2013).

Overall, this study concludes that the dominant attribute of culinary tourism products is a tourist attraction which includes a variety of foods and a distinctiveness of food.

\section{CONCLUSIONS RECOMMENDATIONS}

AND

Of the three attributes of tourism products that were partially tested in this study, only tourist attraction had a significant effect on revisit intension, while accessibility and amenities had no effect. This indicates that in culinary tourism activities, tourist attraction plays an important and dominant role in creating tourist loyalty. There are two components of the main tourist attraction attributes, namely the variety of food and the distinctiveness of the food. Therefore, regional specialties as a culinary tourism attraction need to be preserved. In addition, new foods as a result of community creativity and innovation also need to be supported by their existence so that they enrich the food repertoire in the culinary tourism destination concerned.

However, it does not mean that accessibility and amenities are neglected because simultaneously together with tourist attractions can have a significant effect on revisit intension. The tourist attraction that is supported by easy / smooth accessibility and adequate amenities will increasingly make tourists satisfied, causing their desire to come back to the culinary tourism destinations they visited.

The Bogor City Government and culinary entrepreneurs in the culinary tourism area of Jalan Suryakencana need to collaborate in the development of this area. The government needs to continue to organize this area so that it is free from congestion and more comfortable.
Entrepreneurs need to continue to maintain the quality of their food and provide the basic facilities needed by tourists visiting their places.

\section{REFERENCES}

Baker, D. A., \& Crompton, J. L. (2000). Quality, satisfaction and behavioral intentions. Annals of Tourism Research, 27(3), 785-804.

Chen, C.-F., \& Tsai, D. (2007). How destination image and evaluative factors affect behavioral intentions? Tourism Management, 28(4), 11151122.

Cole, S. T., \& Scott, D. (2004). Examining the mediating role of experience quality in a model of tourist experiences. Journal of Travel \& Tourism Marketing, 16(1), 79-90.

Dinas Pariwisata dan Kebudayaan Kota Bogor. (2020). Data Perkembangan Kunjungan Wisatawan ke Kota Bogor. Retrieved from https://disparbud.kotabogor.go.id/inde x.php/post/index/2/92

Frochot, I. (2013). An analysis of regional positioning and its associated food images in French tourism regional brochures. Wine, Food, and Tourism Marketing, 8408, 77-96. https://doi.org/10.4324/978131504339 5

Gatley, A. (2006). Review of food tourism around the world: Development, management and markets. In C. M. Itall, L. Sharples, R. Mitchell, N. Macionis, \&B. Cambourne (Eds.) (2003). Oxford: Butterworth Heinemann. International Journal of Hospitality Management, 25, 340343.

Holloway, C., Davidson, R., \& Humphreys, C. (2009). The Business of Tourism (8th Edition). England: Pearson Education Limited.

Kautsar, M. A. (2018). Rabbit Town, 'selfie culture' versus awareness of art.

Jurnal IImu Sosial dan Humaniora| 266 
Retrieved from The Jakarta Post website:

https://www.thejakartapost.com/life/20

18/03/30/rabbit-town-selfieculture-

versus-awareness-of-art.html

Khasawneh, M. S., \& Alfandi, A. M. (2019).

Determining behaviour intentions from the overall destination image and risk perception. Tourism and Hospitality Management, 25(2), 355-375. https://doi.org/10.20867/thm.25.2.6

Kivelä, J. J., \& Chu, C. Y. H. (2001). Delivering quality service: Diagnosing favorable and unfavorable service encounters in restaurants. Journal of Hospitality \& Tourism Research, 25(3), 251-271.

Lehto, X. Y., O'Leary, J. T., \& Morrison, A. M. (2004). The effect of prior experience on vacation behavior. Annals of Tourism Research, 31(4), 801-818.

Lin, C. H. (2014). Effects of Cuisine Experience, Psychological WellBeing, and Self-Health Perception on the Revisit Intention of Hot Springs Tourists. Journal of Hospitality and Tourism Research, 38(2), 243-265. https://doi.org/10.1177/109634801245 1460

Long, L. M. (2004). Culinary tourism. University Press of Kentucky.

Mayasari, W. M., \& Budiatmo, A. (2017). Pengaruh Atribut Produk Wisata Dan Word Of Mouth Terhadap Keputusan Berkunjung Pada Objek Wisata Taman Margasatwa Semarang. Jurnal Administrasi Bisnis, 6, 1-8.

Muflikhah, V., Mbulu, Y. P., \& Gunadi, I. M. A. (2018). Pengaruh Electronic Word of Mouth di Media Sosial Instagram dan Atribut Produk Wisata terhadap Keputusan Berkunjung di Floating Market Lembang. Journal of Tourism Destination and Attraction, 6(2), 1629.

https://doi.org/https://doi.org/10.35814 /tourism.v6i2.770
Okumus, B., Okumus, F., \& McKercher, B. (2007). Incorporating local and international cuisines in the marketing of tourism destinations: The cases of Hong Kong and Turkey. Tourism Management, 28(1), 253-261.

Quan, S., \& Wang, N. (2004). Towards a structural model of the tourist experience: An illustration from food experiences in tourism. Tourism Management, 25(3), 297-305.

Rageh, A., Melewar, T. C., \& Woodside, A. (2013). Using netnography research method to reveal the underlying dimensions of the customer/tourist experience. Qualitative Market Research: An International Journal.

Ryan, C. (2002). The tourist experience: The new introduction. London, England: Cassell.

Scarpato, R. (2002). Gastronomy as a tourist product: The perspective of gastronomy studies. In A.-M. Hjalager \& G. Richards (Eds.). In Tourism and gastronomy (pp. 51-70). London: Routledge.

Sparks, B., Bowen, J., \& Klag, S. (2003). Restaurants and the tourist market. International Journal of Contemporary Hospitality Management, 15(1), 6-13. https://doi.org/10.1108/095961103104 58936

Steinmetz, R. (2010). Food, tourism and destination differentiation: The case of Rotorua, New Zealand. Retrieved from

http://aut.researchgateway.ac.nz/bitstr eam/handle/10292/1090/SteinmetzR. pdf? sequence $=3$

Suwantoro, G. (2004). Dasar-dasar pariwisata. Yogyakarta: Andi.

Umar, H. (2003). Metode Riset Bisnis. Jakarta: Gramedia Pustaka Utama.

United Nation World Tourism Organization. (2013). UNWTO Annual Report 2012. Madrid.

Jurnal IImu Sosial dan Humaniora | 267 
Zhang, H., Wu, Y., \& Buhalis, D. (2018). A model of perceived image, memorable tourism experiences and revisit intention. Journal of Destination Marketing and Management, 8(February), 326-336. https://doi.org/10.1016/j.jdmm.2017.0 6.004 